This is a postprint version of the following published document:

María Trinidad García Leiva (2015): Cultural diversity and free trade: the case of the EU-Canada agreement, International Journal of Cultural Policy, DOI:10.1080/10286632.2015.1119131

C2015 Taylor\&Francis 


\title{
Cultural diversity and free trade: the case of the EU-Canada agreement
}

\author{
María Trinidad García Leiva \\ Department of Journalism and Audiovisual Communication, Carlos III University of \\ Madrid, UC3M, Edif. Ortega y Gasset, Calle Madrid 133, Getafe 28903, Spain
}

\begin{abstract}
This article examines the role assigned to culture in general and to cultural industries and diversity in particular by the Canada EU Comprehensive Eco nomic Trade Agreement (CETA). Although it pursues further economic liberal ization, the arrangement is about much more than trade: its preamble, for instance, contains a reference to the 2005 UNESCO Convention on the Diver sity of Cultural Expressions. Nevertheless, the text lacks a general exception clause protecting culture. This paper examines the consolidated CETA text from the perspective of political economy to clarify to what extent this is an opportu nity to reconcile rules of free trade with cultural policies aiming to protect and promote the diversity of cultural expressions, especially when the latter derive from cultural industries in both analogue and digital scenarios.
\end{abstract}

Keywords: cultural policy; diversity; digital era; UNESCO; WTO

\section{Introduction}

In May 2009 negotiations between Canada and the European Union (EU) toward a Comprehensive Economic and Trade Agreement (CETA) were launched. ${ }^{1}$ Over the years, the agreement turned out to be deeper and broader than any previous arrangement (for example, the North American Free Trade Agreement, NAFTA). The word 'comprehensive' that is included in its title refers to the fact that negotiations have been truly broad, including all business sectors, and deep, taking into consideration tariff and non-tariff barriers to trade.

For the European Commission (EC), the CETA is a treaty that, once applied, will offer EU firms more and better business opportunities in Canada and support jobs in Europe. It will tackle a whole range of issues to make business with Canada easier: from removing customs duties and ending limitations in access to public contracts, to helping prevent illegal copying of EU innovations and traditional prod-ucts. Mirroring this discourse, the government of Canada assures that the agreement will open new markets to Canadian exporters throughout the EU and will generate significant benefits for its nationals, especially in terms of creating jobs and oppor-tunities in every region of the country.

EC lawyers are currently reviewing the consolidated text (Canada-EU 2014), and once it is translated into all official EU languages, it will be discussed in the EU Council and the European Parliament. Providing both approve the agreement in 
2015, and a similar process takes place in Canada, it could be applied in 2016. While the text may undergo some changes during the scrubbing process, both parties consider it closed. Therefore, no substantial changes are in fact expected.

The secrecy and democratic deficit surrounding negotiations were very much criticized from the beginning, and a consolidated version of the agreement was not actually made public until it was leaked in August 2014 by the German state broadcaster ARD, after negotiators from the EC and Canada had finalized their work early that month. ${ }^{2}$ The text was made public when EC President Jose Manuel Barroso, European Council President Herman Van Rompuy and Canadian Prime Minister Stephen Harper announced the end of the CETA negotiations at the EU-Canada Summit on September 26, 2014. It seems that 'both sides have committed to sign off on the final text before any meaningful public debate can possibly take place. This take-it or leave-it approach leaves little room for the citizens of Canada or the EU to assess CETA's potential impacts, let alone advocate for changes' (Sinclair et al. 2014, $5)$.

In this context, the question about the capacity of the CETA to actually protect and promote the diversity of culture is therefore important because, despite the fact that its preamble states that it aims to strengthen economic relationships, the arrangement is about much more than trade. It is worth noting that it includes an explicit reference to the commitments of both parties to the 2005 UNESCO Con-vention on the Protection and Promotion of the Diversity of Cultural Expressions (hereafter, the 'UNESCO Convention'; UNESCO 2005), and underlies their right to preserve, develop and implement their cultural policies as well as to support their cultural industries for the purpose of strengthening the diversity of cultural expres-sions and preserving their cultural identity (including the use of regulatory mea-sures and financial support). Nevertheless, the text lacks a general exception clause protecting culture. What has been agreed is that some chapters contain articles exempting culture. Whereas for the EU this applies only to audiovisual services, for Canada it covers all cultural industries.

Is this a missed opportunity for both Canada and the EU to safeguard culture from trade, to reconcile rules of free trade and cultural policies? Can the inclusion of the UNESCO Convention in the CETA text help counterbalance and resist those principles of free trade that undermine necessary and legitimate cultural policies and regulations aiming to protect and promote the diversity of cultural expressions, especially those that are the product of cultural industries? This paper seeks to explore answers to these questions by examining the role assigned to culture in general and to cultural industries and diversity in particular by the CETA text.

To do so, a multidisciplinary critical approach that endeavors to connect politi-cal and economic logics, along with proper historical contextualization, is proposed, in order to lead to a framework that goes beyond mere or partial description. In Mosco's words (1996), it is about going beyond the understanding of the what, who or how, to determine the why; the why in this case referring to the actual importance of the EUCanada trade agreement for the field of culture. In terms of method, a documentary analysis was conducted, taking the consolidated CETA text (Canada-EU 2014) as a point of departure to put it in relation to existing analyses about its negotiation and aims as well as the UNESCO Convention.

After providing contextual and historical information about the agreement within the so-called trade and culture debate, to justify and explain why the CETA is important as a case of study, key points concerning cultural exemptions will be 
examined from the perspective of political economy to clarify to what extent there will be room for maneuver to actually protect and promote the diversity of cultural industries, both in analogue and digital scenarios.

\section{The trade and culture quandary}

Audiovisual products occupy a significant place within cultural expressions because they constitute the main source of entertainment and information for many people as well as an important economic sector in some countries. According to Ofcom (2014), for example, the US had the highest level of TV viewing in 2013 (293 min per person per day), while the European Audiovisual Observatory estimated that the audiovisual turnover of the 50 leading worldwide media groups rose from USD 361.5 billion to USD 425 billion from 2009 to 2013 (Grece et al. 2015). This dual nature of audiovisual productions, both cultural and economic, has led to multiple tensions between the social values conveyed by the existence of a diversity of cul-tural expressions and the economic benefits of their commercialization. These issues, often perceived as dilemmas, have been especially controversial with the increase of international market integration and the negotiation of bilateral and mul-tilateral trade agreements.

In fact, since the 1920s when some European countries introduced film quotas, policies and regulations designed to protect and promote cultural expressions have been under increased scrutiny and pressure from international trade negotiations with liberalizing aims. This trade and/vs. culture debate, which became particularly heated during the Uruguay Round of the General Agreement on Tariffs and Trade (GATT) negotiations (1986-1994), has been extensively dealt with among scholars. An initial and by no means exhaustive review of academic literature can highlight the fact that while some have concentrated on the economic side of this debate (Guerrieri et al. 2005), others looked more specifically into sociopolitical aspects (Mattelart 2006) or regulatory issues (Sauvé and Steinfatt 2000). In any case, a comprehensive and clarifying account that also explains the role and importance of concepts such as 'cultural exception' can be found in Bernier (2005).

In the context of such a long lasting debate, the UNESCO Convention repre-sents a milestone in terms of filling an existing lacuna for cultural objectives in international law and serving as a counterbalance to the World Trade Organization (WTO) (Graber 2006, Obuljen and Smiers 2006). Not in vain, its ratification was put forward as a response to the attempts to completely liberalize audiovisual ser-vices on a global scale and was foreseen as a tool at the confluence of law and pol-itics (Bernier 2008).

Approved on October 20, 2005, the UNESCO Convention came into force in 2007 after a fast-speed ratification process. As of June 2015, 137 States as well as the EU have ratified this treaty, whose relevance lies within legally binding provi-sions that declare, for example, that cultural activities, goods and services have a dual nature (Article 1), and that States have the right to maintain, adopt and imple-ment cultural policies and measures (Article 6). Whereas detailed legal analyses about the Convention can be found in Bernier and Ruiz Fabri (2006), Barreiro (2011) and Von Schorlemer and Stoll (2012), studies about its implementation and effectiveness are more recent (Richieri Hanania 2014, Loisen 2015, De Beukelaer et al. 2015), especially as regards the digital era (Guèvremont 2013, Beaudoin 2014, Kulesz 2014, Rioux et al. 2015). 
Among those particularly interested in the UNESCO Convention as an international tool for regulating the interface between trade and culture (Burri 2011, Vlassis 2011, 2015), some argue that the historical opposition between economic and cultural interests might in fact be evolving towards a rather complementary relationship (Vlassis and Richieri Hanania 2014). For example, the European experience in implementing the UNESCO Convention through cultural cooperation mechanisms, such as the protocols on cultural cooperation, would prove that the promotion of cultural exchanges may be addressed independently from trade and market access provisions in the cultural sector (Richieri Hanania 2012, SouyriDesrosier 2014). ${ }^{3}$

Furthermore, in Thiec's words (2014), we would be witnessing a kind of moratorium in the international community because the Convention would have led to a reasonable mediation of potential conflicts between both trade regulation and cul-tural exchanges. In doing so, the tendency to make the WTO the main regulating body for commercial exchanges would have been slowed down. The foregoing cir-cumstance would partially explain the multiplication of bilateral and multilateral agreements beyond the WTO, such as the CETA, the TTIP, the Trans-Pacific Partnership Agreement (TPP) and the Trade in Services Agreement (TiSA). ${ }^{4}$ In Wunsch-Vincent and Hold's view (2011), the lack of progress achieved on the mul-tilateral level since the end of the Uruguay Round has, for instance, prompted regional and bilateral agreements to secure liberal digital trade.

While the outcome of this network of arrangements will certainly shape world trade and investment in the twenty-first century, affecting international cultural exchanges, the question is why the CETA is especially important among them. It is maintained here that its relevance lies in the fact that it could be used as a prece-dent and template for other agreements, launching a new episode of the trade and culture debate, this time, right into the digital era. In this sense, Thiec's impasse may vanish soon if parties to the Convention do not address digital issues within its framework promptly. This piece aims to make a contribution to the trade and culture debate sketched here, clarifying whether or not the EU-Canada trade agree-ment heads in that direction.

\section{The EU-Canada trade agreement}

The CETA is the first trade agreement between the EU and a major world economy and the most far-reaching bilateral negotiation to date because it is not a traditional free trade agreement such as the NAFTA, where customs duties (tariffs) on trade in goods and services are eliminated. The CETA is a second-generation trade agree-ment (Leblond 2010, Hübner 2011) where the emphasis is on non-tariff barriers such as standards, procedures and regulations, since they have, for instance, become the main source of trade impediments. Tariffs are already quite low - espe-cially between rich countries - as a result of the GATT and the WTO.

It is a truly new beast of agreement (Hübner 2014) because it opens up public procurement (the public purchasing of goods and services of all kinds), it moves into the realms of private property rights and national regulation regimes, it includes subsectors of the agricultural industry, and, most critically, it provides the basis for a partnership where both sides are to some significant degree integrated into global and sub-global value chains. What, then, are some of the issues the CETA presents? 
Public services, for example, face huge challenges because of the 'negative list' approach the agreement is based on (Sinclair et al. 2014). This means that the liberalizing provisions affect all public services unless explicitly ruled out by negotiators. ${ }^{5}$ This 'list it or lose it' perspective is a serious threat for the future of many public services. Likewise, as regards intellectual property rights, the extension of patents was on the table of negotiations from the very beginning. And although most of the initial EU demands on copyright and related rights have been withdrawn, changes to Canadian patent protection for pharmaceuticals are expected to delay the availability of cheaper, effective generic drugs for Canadians (Sinclair et al. 2014).

Undoubtedly, one of the most controversial aspects of the agreement is the investor-state dispute settlement (ISDS) mechanism, which has raised much concern in Canada and many of the EU's member states (e.g. Germany) and is most proba-bly going to be rejected by a large bloc of parties in the European Parliament. The ISDS mechanism and the Investment Protection section pave the way for foreign corporations to seek compensation from governments for any measure that may hurt their investments, outside the regular court system. Very briefly, and in Fuchs' words (2014, 13 -14): 'foreign investors will be granted the special privilege of suing host governments and claiming compensation for all kinds of state actions, while bypassing domestic judicial systems and their independent courts'; the CETA does not require investors to first resort to domestic courts in solving disputes and it does not clearly and unequivocally confirm the state's right to regulate.

Friends of the Earth Europe has recently demonstrated (Geraghty and Cingotti 2014), after compiling publicly available data on ISDS cases taken against EU member states since 1994, that the use of this mechanism has been affecting states for years and it has already cost EU taxpayers $€ 3.5$ billion. 'Canada's experience with NAFTA amply illustrates the dangers of investment arbitration. There have been 35 investor-state claims against Canada under NAFTA, and the number continues to grow. So far, Canada has lost or settled six claims and paid damages to foreign investors totaling over C $\$ 171.5$ million ( $€ 121$ million). Canadian taxpayers have also paid tens of millions of dollars in legal costs defending against these claims' (Eberhardt et al. 2014, 5).

Negotiations between the EU and Canada have been criticized not only because of secrecy but also for having been developed closely and almost exclusively in collaboration with industry lobby groups that have had privileged access to negotiation texts (The Council of Canadians 2013).

\section{The CETA, culture and diversity}

So what is, more specifically, the matter with culture and diversity? Even though negotiations failed to include a general exemption, the agreement has an explicit reference to the commitments of both parties to the UNESCO Convention and it includes articles exempting culture in five chapters. What do these mean? What is the role assigned to culture in general and to cultural industries and diversity in particular? Before trying to answer these questions, the debate about culture dur-ing negotiations, as well as the presence of the Convention in the preamble of the agreement and the content and scope of cultural exemptions, have to be explained. 


\section{The negotiations: a 'general exclusion' vs. a 'targeted approach'}

Among those willing to safeguard culture from trade, there have been two main positions: the one identified as the 'horizontal' or 'general exclusion' approach, in contrast to the 'flexible' or 'targeted' approach. The former, supported by the French Coalition for Cultural Diversity and publicly endorsed in 2013 by individu-als such as Bernard Cazeneuve (then French Minister Delegate for European Affairs) and Louise Beaudoin (former Minister of International Relations and Min-ister for the Francophonie), demanded the total exclusion of culture from negotia-tions. The latter, contained in the proposal of Canada and Quebec's chief negotiators and supported by the Coalition for Cultural Diversity, was presented as a way to reconcile Canadian and European visions via establishing exemptions chapter by chapter (a 'negative list' approach).

The rationale behind this perspective, successful in the wording of the text, is that a flexible way of pursuing cultural exemption is the best way to guarantee an agreement between Europe and Canada. Whereas the EU includes an exemption limited to audiovisual services only in the services chapter in all of its free trade agreements, Canada maintains a notion of cultural exemption that covers all cul-tural industries in all chapters of its trade agreements. During the bilateral negotia-tions on the CETA, Quebec and France exerted pressure to have a cultural exception explicitly included in the deal. But 'although Canadian and European political leaders and negotiators agreed on the principle, leaked documentation showed that the negotiating parties disagreed on the scope of the cultural exemp-tion and on how to fulfill Canada and the EU member state obligations under the UNESCO Convention. This is reflected in the final text' (Maltais 2014b, 51).

In other words, the CETA wording as regards culture has to be understood as the outcome of the Canadian threefold strategy in combination with the EC's change in policy direction that took place around November 2012. Canada's strat-egy aimed to: (a) express cultural considerations in the preamble, (b) include its tra-ditional definition of cultural industries with exceptions limited to selected chapters, and (c) make reservations on specific cultural sectors and regulations in the annexes. As regards the $\mathrm{EU}$, the EC, which pronounced itself in favor of exempting audiovisual services from the negotiations with Canada, ended up supporting their inclusion via the mechanism of building 'negative lists'.

\section{The wording: between the UNESCO Convention and specific cultural exemptions}

The preamble of the CETA, in a page and half of a 537-page document (1634 with annexes), contains two references to culture (Canada-EU 2014, 6 -7):

RECOGNIZING that the provisions of this Agreement preserve the right to regulate within their territories and resolving to preserve their flexibility to achieve legitimate policy objectives, such as public health, safety, environment, public morals and the promotion and protection of cultural diversity; and

AFFIRMING their commitments as Parties to the UNESCO Convention on the Protection and Promotion of the Diversity of Cultural Expressions and recognizing that states have the right to preserve, develop and implement their cultural policies, and to support their cultural industries for the purpose of strengthening the diversity of cultural expressions, and preserving their cultural identity, including through the use of regulatory measures and financial support. 
Whereas the first reference underlines the promotion and protection of cultural diversity as a legitimate policy objective, the second gives context by referring to the UNESCO Convention and its principles. According to the Coalition for Cultural Diversity (CCD 2014), this sets a precedent because this is the first time that a reference to the UNESCO Convention is included in the preamble of a trade agree-ment. Nevertheless, it cannot be forgotten that although the content of the preamble is supposed to contribute to the interpretation of the agreement and offer context to potential disputes, the weak wording of the UNESCO Convention casts many doubts as to its normative strength (Richieri Hanania and Ruiz Fabri 2014).

As regards the so-called cultural exemptions, they are limited to five of the nearly three dozen chapters of the agreement: Subsidies, Investment, Cross-Border Trade in Services, Domestic Regulation and Government Procurement (see Table 1). The chapter on subsidies completely exempts these and government support from any provision of the agreement, but elsewhere the exclusion is either limited to the chapter or its relevant provisions.

In Maltais' words (2014a), the CETA includes a partial and asymmetric cultural exception: partial as it is only applicable in some chapters, asymmetric because for the EU the exception only applies to audiovisual services, whereas for Canada, it covers all cultural industries, as usually defined in its trade agreements.

Such a definition is found in Chapter 32, Exceptions, where a reminder of the scope of the cultural exemption is also included (Canada-EU 2014, 455-461):

'Article X.01: Definitions

/.../

Cultural industries means a person engaged in:

(a) the publication, distribution or sale of books, magazines, periodicals or newspapers in print or machine readable form, except when printing or typesetting any of the foregoing is the only activity;

(b) the production, distribution, sale or exhibition of film or video recordings; the pro duction, distribution, sale or exhibition of audio or video music recordings; the publi cation, distribution or sale of music in print or machine readable form; or radio communications in which the transmissions are intended for direct reception by the general public, and all radio, television and cable broadcasting undertakings and all satellite programming and broadcast network services.

/.../

X.08: Cultural Industries

The parties recall the exceptions applicable to culture as set out in the relevant provi sions of Chapters X, Y and Z (Cross Border Trade in Services, Domestic Regulation, Government Procurement, Investment, Subsidies)'.

It should not be forgotten that the EU's $d$ e finition of audiovisual services must be traced back to the Audiovisual Media Services Directive (European Union and Council 2010), where 'audiovisual media service' refers to a service which is under the editorial responsibility of a media service provider and the principal purpose of which is the provision of programs to the general public by electronic communica-tions in order to inform, entertain or educate. Such an audiovisual media service is 


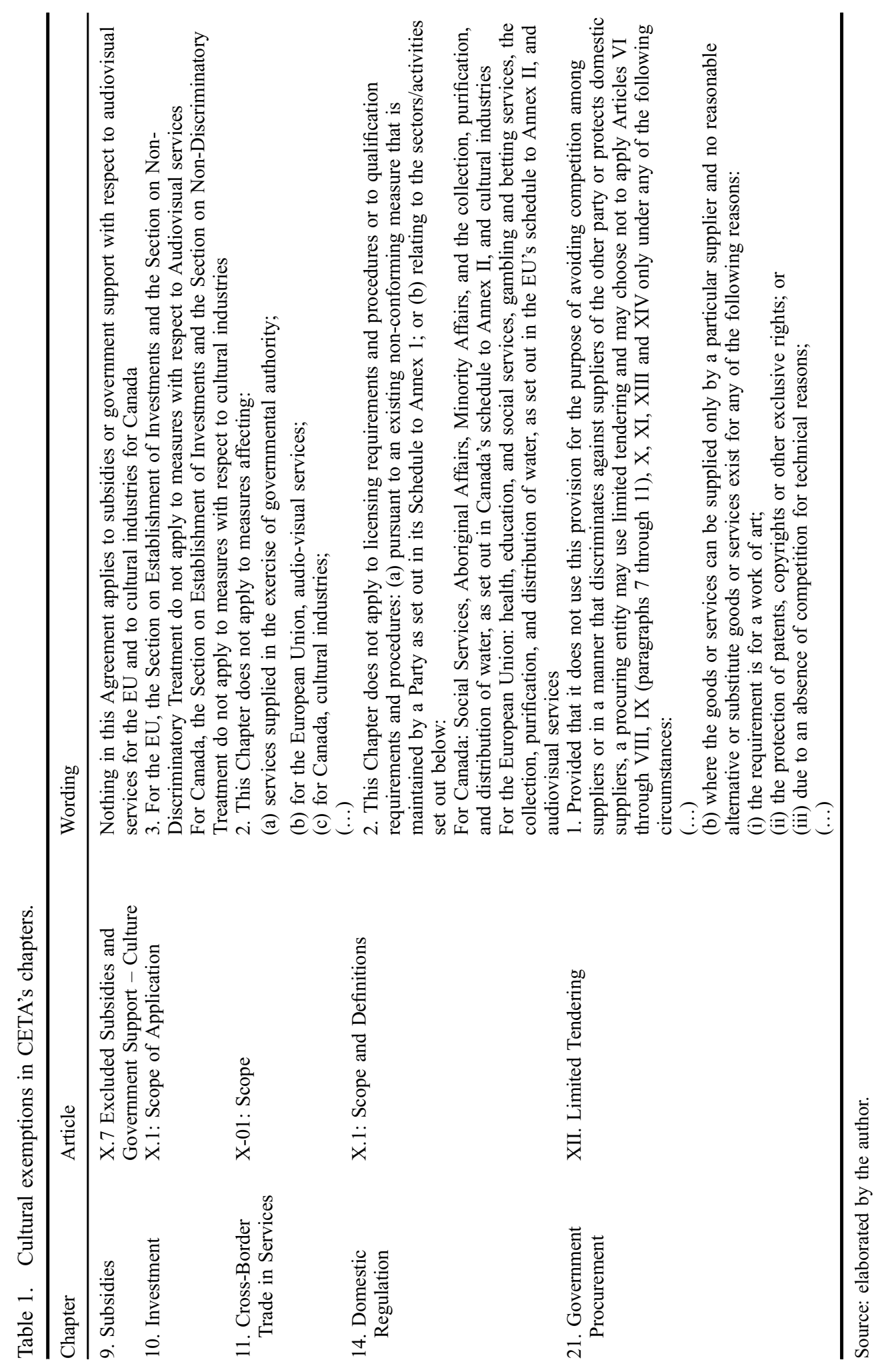


either a television broadcast or an on-demand audiovisual media service. While the former refers to a service provided for simultaneous viewing of programs on the basis of a program schedule (i.e. a linear audiovisual media service), the latter implies a service provided for the viewing of programs at the moment chosen by the user and at his individual request on the basis of a catalogue of programs selected by the media service provider (i.e. a non-linear audiovisual media service). In any case, it must be pointed out that this is a narrower definition than the one used by the WTO (EBU 2014), which includes radio, cinema projection services, motion picture productions, sound recording and other services.

What about culture beyond the Canadian definition of cultural industries and the European conceptualization of audiovisual services? In other words: what might be the effects of the provisions contained in the agreement on, for example, live performances, video games or web design? The answer is below: what is not explicitly exempted is not protected.

\section{The implications: 'list it or lose it!'}

The supporters of the 'targeted' or 'flexible' perspective maintain that advantages are numerous (CCD 2013), considering that the inclusion of the UNESCO Conven-tion in the preamble clarifies the grounds on which Canada and the EU agree to cultural exemptions:

- The 'chapter by chapter' approach establishes the perimeter of cultural sovereignty with greater precision because it reassures that the counterpart recognizes exempting intentions.

- It gives flexibility not to demand a cultural exemption in chapters that are irrelevant or that should not be weakened (e.g. the one about intellectual prop-erty).

- And it could be requested in the future by Canada and the EU when dealing with other partners that oppose cultural exemptions.

Contrary to this perspective, critics such as the French Coalition for Cultural Diversity (FCCD 2012) are of the opinion that 'negative lists' do not afford the same protection as a 'horizontal exclusion' because listing sectors to be included in annexes will ultimately define and delimit their scope for future application. The ability of states to develop new policies can be hampered while the capacity of trading partners to define listed sectors as narrowly as possible to limit the scope of protection is enabled.

In other words, whereas a 'horizontal exclusion' helps states maintain autonomy and avoid embroiled negotiations, the 'negative list' approach includes, ipso facto, all services among those liberalized under the agreement, leaving aside only what is explicitly listed as excluded in the annexes. The risk consists of leaving certain cultural domains under the pressure of trade negotiations and neglecting those sec-tors that could be very important with the arrival of new technologies (Burri 2015, Vlassis 2014). As Sauvé and Steinfatt (2000) put it, in the conflictive domain of trade and culture, the net benefits of giving content to the law ex ante through legislation exceed those of giving content to the law ex post through adjudication.

Some observations can therefore be made about the impact of the CETA on cul-tural policy-making. Since the EU only demands an exception for (some) audiovisual 
services, other cultural productions such as live performances (theatre, concerts, and circus) or book, magazine and newspaper publishing will fall under the provisions of the agreement. Following on from this, it is possible that some measures, like the fixed prices for books, could be called into question (Blinn 2015). Due to the wording of Chapter 10, Investment, article X.3, the expression 'the expectation of gain and profit' in the definition of what an investment is (Canada-EU 2014, 149) may open the door to companies to use ISDS mechanisms to challenge this type of national pol-icy for being a barrier to trade.

In the case of Canada, since provinces participated in negotiations they submitted their own offers sometimes including reservations in areas of their jurisdictions. With the exception of Quebec, few 'cultural reservations' were made (Maltais 2014b, 54): in regard to government procurement market access, for example, Quebec included a broad reservation, making explicit that procurement liberalization disciplines would not apply for public contracts awarded by Quebec entities for works of art from local artists or to procurement by any municipality, academic institution or school board of other provinces and territories related to cultural industries (see Canada-EU 2014, 54, Annex X-07). The procurement commitments that Canada has agreed to are extensive and will substantially restrict the vast majority of provincial and municipal government bodies from using public spending as a catalyst for achieving societal goals (Trew 2014, 25). Among these, there are, of course, the protection and/or promotion of culture.

\section{Final remarks}

What, then, is the role the CETA assigns to culture in general and to cultural indus-tries and diversity in particular since negotiations led to the decision to reconcile culture and trade via the inclusion of the UNESCO Convention in the preamble and the specification of some exemptions in a 'chapter by chapter' approach?Because a general exemption was ruled out for culture, which means that there is a general and de facto inclusion of it, it is maintained here that the role assigned to culture and its diversity is secondary and subsumed to free trade relationships.

The fact that exemptions are confined to specific chapters, and that they apply to audiovisual services for the EU and to cultural industries for Canada, reveals dif-ferent interpretations in the scope of the cultural exception and a partial and asym-metric protection whose evolution is uncertain. The audiovisual sector might not be at risk but, in the absence of a general cultural exception, non-audiovisual invest-ment measures or subsidy programs could be mutually challengeable unless specifi-cally identified and grandfathered. Tensions may arise between the EU and Canada if large enterprises consider they are being affected by cultural policies and decide to use investor-to-state dispute mechanisms.

But the problem is not just that existing cultural expressions are partially and asymmetrically protected because there are divergent perspectives about the matter. Concern should be directed too toward the future: into the digital era. With the exception of subsidies, which are completely exempted, cultural exemptions are limited to some chapters and relevant provisions. This means that what is not actu-ally and explicitly included in the articles or the list of specific reservations of each party is not protected. Take for instance the list of reservations made to Chapter 35 (Services and Investment): words such as 'digital' or 'internet' are completely absent. In addition, it is worth noting that Canada and the EU have agreed to 
'import' Article XX of the GATT and to make it applicable to all CETA chapters (Maltais 2014b, 53). Article XX contains the exceptions to the General Agreement which include no 'cultural exception' per se as the provisions limit its scope to the 'protection of national treasures of artistic, historic or archaeological value' Arti-cle XX(f). ${ }^{6}$ While the analogue past might be well served, the digital future of the diversity of cultural expressions is consigned to oblivion.

Some insist on the opportunities that may arise from the inclusion of the UNESCO Convention in the agreement $(C C D, 2013)$ to mitigate, for example, the risks of the logic of partial exemptions. It is not a minor thing that, for the first time since its adoption, the Convention is referenced in the preamble of a trade agreement. The CETA is innovative in this respect, expressing the best intentions of the parties to protect and promote cultural diversity. But as we all know, the road to hell is paved with good intentions. Therefore, the (soft) regulation effect that the UNESCO Convention can have will succumb to the (prescriptive) one that the specific provisions - the chapters - will have. The preamble may contribute to mitigating the negative impact of liberalization measures, because a treaty must be interpreted in light of its object and purpose, but where free trade rules are in con-flict with cultural protection and promotion policies, panelists or arbitrators would be more likely to favor the former (Maltais 2014b, 51). In fact, WTO jurisprudence has so far rejected the interface between the UNESCO Convention and the WTO Agreements (Burri 2015).

From our point of view, the risks of relying on the logic of specific exemptions for existing services to face the digital era greatly outweigh the benefits the refer-ence to the UNESCO Convention may provide. Many have already cited the chal-lenges the Convention poses to adapting cultural diversity to the new digital environment (e.g. Frau-Meigs 2012, Guèvremont 2013, Thiec 2014). The GATS may not pose any imminent threat to countries that have not made specific commit-ments (Canada and the EU, for instance), but attempts to reclassify audiovisual services as e-commerce and the difficulties this entails have not disappeared (e.g. digital video on demand or online gaming; Puppis 2008, Burri 2015).

Vlassis and Richieri Hanania (2014) point out that because of the economic growth potential of information and communication technologies and the compara-tive advantage of the US in this field, one of this country's main priorities is now to include non-linear audiovisual services in the agenda of trade negotiations instead of challenging the financial and regulatory capacity of governments in the field of traditional linear services (such as conventional TV, DVDs or movies). The aim is to 'prevent the implementation of regulatory measures in the new technolo-gies fields, on internet service providers and new audiovisual services which repre-sent the future of the sector' (Vlassis and Richieri Hanania 2014, 33). Take for instance the example of Netflix (Vlassis 2015): according to the US Congress (Bipartisan Congressional Trade Priorities Act of 2014), current obligations, rules, disciplines, and commitments under the WTO and bilateral and regional trade agreements must apply to such a (digital) service. Following this logic, e-commerce and information and communication technologies sectors would have nothing to do with culture.

Furthermore, even though issues of culture and knowledge in the digital era unquestionably need to be placed within the jurisdiction of the UNESCO Conven-tion, the problem is that the treaty is based on a classical, geographically-based approach to sovereignty, whereas the internet is not: 'internet services do not fit 
automatically to the jurisdiction of the destination or recipient country and this undermines the exercise of sovereignty by the Parties,' as defined by the UNESCO Convention (Thiec 2014, 101).

So, to sum up, it can be said that the inclusion of cultural considerations in the CETA preamble and the reference to the UNESCO Convention are to be applauded (Maltais 2014a, Vlassis 2014), but as the sole strategy for protecting and promoting the diversity of current and future (digital) cultural expressions, the outcome is uncertain (Vlassis 2015). The inclusion of the UNESCO Convention as an interpretative tool will have a hard time counterbalancing and helping to resist free trade commitments when they undermine the diversity of cultural expressions. The 'list it or lose it' approach will indeed hinder the capacity of states to update and adapt cultural policies to the digital era.

The CETA is therefore a missed opportunity for both Canada and the EU to reconcile rules of free trade and cultural policies in the sense of building bridges between culture and trade in international law: for some this could have been achieved by having a specific chapter dedicated to culture (as it is already the case in the CETA with the environment; Vlassis and Richieri Hanania 2014) o r b y adding a Protocol on Cultural Cooperation to the agreement (as was at some point suggested by Quebec). Others are of the opinion that this reconciliation should be done by amending and renovating WTO law norms (Burri 2011).

In any case, it is worth noting, too, that it is not just a lost opportunity in this respect. It is also a worrying precedent for future bilateral or multilateral agree-ments for those who look at the text with the anticipation of finding clues for the TTIP, the TPP and the TiSA. ${ }^{7}$ As Souyri-Desrosier (2014) acutely reminds us, a good deal of attention should be paid to negotiations with countries such as Japan or the US, which are not parties to the UNESCO Convention and have a special interest in the audiovisual and so-called 'new' (digital) services.

The CETA might well be about to kick off the trade and culture debate again, this time, though, right into the digital era.

\section{Acknowledgments}

The author would very much like to thank Professors Guillermo Mastrini and Antonios Vlassis for their comments on early drafts of this paper.

\section{Disclosure statement}

No potential conflict of interest was reported by the author.

\section{Funding}

This work is based on research undertaken for the project 'Diversity of the Audiovisual Industry in the Digital Age' [CSO2014 52354R], diversidadaudiovisual.org, supported by the Spanish Ministry of Economy and Competitiveness within the National RDI Program Aimed at the Challenges of Society.

\section{Notes}

1. Current trade relations between Canada and the EU are guided by a Framework Agree ment for Commercial and Economic Cooperation, in force since 1976. The EU and Canada meet annually in bilateral summits and in the Joint Cooperation Committee to 
review a range of issues related to economic and trade relations. Over the years, a num ber of additional bilateral agreements designed to facilitate trade have been concluded. Nevertheless, at the 2007 EU Canada Summit in Berlin, it was agreed to complete a joint study examining the costs and benefits of pursuing a closer economic partnership (Canada EU 2008), which was followed by a 'scoping exercise' to establish the areas for negotiation (Canada EU 2009). This exercise paved the way for the launch of actual negotiations at the 2009 EU Canada Summit in Prague.

2. In Canada, unions and civil society organizations issued a declaration in 2011 against ongoing negotiations, and more and better information about the deal has been available in recent years thanks to the efforts of initiatives such as the Trade Justice Network or organizations like the Canadian Centre for Policy Alternatives or The Council of Cana dians. In Europe, 300 groups gathered around the Stop TTIP Coalition and filed a law suit against the EC over its failure to publically review its policy on the CETA and the Transatlantic Trade and Investment Partnership (TTIP). In any case, it is for sure that the European Parliament, as the EU's negotiator, will scrutinize whether the EC suc ceeded in striking the right balance between economic liberalization and consumer pro tection (Bierbrauer 2014).

3. Protocols on cultural cooperation are instruments for cultural cooperation put forward by the European Commission in the way of annexes to a trade agreement; in fact, they contain explicit references to the UNESCO Convention because they were developed to promote its principles and implementation in the framework of EU relations with third countries (Souyri Desrosier 2014, 210). Whereas the first was concluded in 2008 with the Cariforum, negotiations with Central Africa are ongoing.

4. Whereas the trade and investment deal between the EU and the US (TTIP) was launched in 2013 and the European Commission publicly presented its negotiating texts on January 7, 2015, the TPP is a regulatory and investment treaty involving countries throughout the Asia Pacific region (Australia, Brunei, Canada, Chile, Japan, Malaysia, Mexico, New Zealand, Peru, Singapore, the United States, and Vietnam). The treaty dates back to 2005 and is still under negotiations (the last round meeting took place in Ottawa from July 312,2014$)$. The TiSA is yet another trade agreement which has been negotiated since February 2012 by 23 members of the WTO including the EU and the US, the main proponents.

5. This top down or negative listing approach, where everything is committed unless specifically excluded, is in any case the rule in bilateral trade negotiations. This was the case with negotiations on the never adopted Multilateral Agreement on Investment (1995 1998). The bottom up or positive list approach, where the sectors in which com mitments are undertaken are selected individually, is the one followed by the WTO.

6. The complete text of Article XX with interpretative notes can be found in https://www. wto.org/english/res e/booksp e/gatt ai e/art20 e.pdf.

7. Some interesting preliminary contributions have already been published. See, for instance, Zimmermann and Geißler (2015) or Cardoso et al. ( 2013).

\section{Notes on contributor}

María Trinidad García Leiva is a visiting lecturer in the Department of Journalism and Audiovi sual Communication of the Carlos III University of Madrid (UC3M). She is a member of the research group TECMERIN and has been an academic visitor to the PCMLP (University of Oxford, 2005) and the CCPR (University of Glasgow, 2009). She leads the project 'Diversity of the Audiovisual Industry in the Digital Age' CSO2014 52354R (diversidadaudiovisual.org). Her main research areas are: cultural diversity, development of the audiovisual digital sector within cultural industries and international cooperation in communication and culture.

\section{References}

Barreiro, B., 2011. La diversidad cultural en el Derecho internacional: la Convención de la UNESCO [Cultural Diversity in International Law: the UNESCO Convention]. Madrid: Iustel. 
Beaudoin, L., 2014. Convention sur la protection et la promotion de la diversité des expres sions culturelles : Impacts et enjeux du numérique [Convention on the Protection and Promotion of the Diversity of Cultural Expressions: impacts and digital issues]. Report within the mandate given by the International Organization of the Francophonie, April, Paris. Available from: http://cdc ccd.org/IMG/pdf/Francophonie Rapport final Conven tion dc 200519 mai 20142 .pdf [Accessed 10 Jun 2015].

Bernier, I., 2005. Trade and culture. In: P. Macrory, A. Appleton, and M. Plummer, eds. The World Trade Organization. Legal, economic and political analysis, vol. II. New York: Springer, 747794.

Bernier, I., 2008. La Convención sobre la diversidad de las expresiones culturales de la UNESCO: un instrumento cultural en la confluencia del derecho y de la política [The UNESCO Convention on the Diversity of Cultural Expressions: a cultural tool between law and politics]. Bulletin de nouvelles sur la diversité des expressions culturelles, 8 (19), 1 27.

Bernier, I. and Ruiz Fabri, H., 2006. Implementing the UNESCO Convention on the Protec tion and Promotion of the Diversity of Cultural Expressions future actions. Quebec: Direction générale du secrétariat et des communications, Ministère de la Culture et des Communications. Available from: http://www.diversite culturelle.qc.ca/fileadmin/docu ments/pdf/UNESCO anglais.pdf [Accessed 12 May 2015].

Bierbrauer, E., 2014. Negotiations on the EU Canada Comprehensive Economic and Trade Agree ment (CETA) concluded. Brussels: Directorate General for External Policies. Available from: http://www.europarl.europa.eu/RegData/etudes/IDAN/2014/536410/EXPO IDA\%282014\%2 9536410 EN.pdf [Accessed 12 May 2015].

Blinn, H., 2015. CETA und wie weiter. Mehr Transparenz und genauere Erklärungen sind bei CETA und TTIP dringedn erforderlich. Bisher bleibt beides lückenhaft [CETA and next steps. More transparency and detailed explanations are urgently needed about CETA and TTIP. So far, both remain sketchy]. In: O. Zimmermann and T. Geißler, eds. TTIP, CETA \& Co. Die Auswirkungen der Freihandelsabkommen auf Kultur und Medien [TTIP, CETA \& Co. The impact of free trade agreements on culture and media]. Berlin: Deutscher Kulturrat, 181189.

Burri, M., 2011. Reconciling trade and culture: a global law perspective. The journal of arts management, law and society, 41, 121.

Burri, M., 2015. The European Union, the World Trade Organization and Cultural

Divensity. Psychogiopoulou, ed. Cultural Governance and the European union protecting and promoting cultural diversity in Europe. Bansingstoke: Palgrave Macmillan, 195209.

Canada EU, 2008. Assessing the costs and benefits of a closer EU Canada economic partner ship. A joint study by the European Commission and the Government of Canada [online]. Available from: http://trade.ec.europa.eu/doclib/docs/2008/october/tradoc 141032.pdf [Accessed 12 May 2015].

Canada EU, 2009. Canada European Union Joint Report: Towards a Comprehensive Eco nomic Agreement [online]. Available from: http://www.international.gc.ca/trade agree ments accords commerciaux/agr acc/eu ue/can eu report can ue rapport.aspx?lang=eng [Accessed 12 May 2015].

Canada EU, 2014. Consolidated CETA text [online]. Available from: http://trade.ec.europa. eu/doclib/docs/2014/september/tradoc 152806.pdf [Accessed 12 May 2015].

Cardoso, D., Mthembu, P., Venhaus, M., and Verde, M., eds., 2013. TheTransatlantic Colossus. Global Contributions to Broaden the Debate on the EU US Free Trade Agree ment. Berlin: Berlin Forum on Global Politics, Internet \& Society Collaboratory and FutureChallenges.org.

CCD (Coalition for Cultural Diversity), 2013. Cultural exemption: reaching an agreement with the Europeans [online]. Available from: http://www.cdc ccd.org/Exemption cul turelle trouver un?lang=en [Accessed 12 May 2015].

CCD (Coalition for Cultural Diversity), 2014. The Canada EU Commercial and Econo mic Trade Agreement: Text Analysis [online]. Available from: http://cdc ccd.org/IMG/ pdf/20141027 CCD Analysis Cultural Exemption CETA ENG.pdf [Accessed 12 May

De Beukelaer, C., Pyykkonen, M. and Singh, P.J., eds., 2015. Globalization, Culture and Development: The UNESCO Convention on Cultural Diversity. Basingstoke: Palgrave Macmillan. 
Eberhardt, P., Redlin, B., and Toubeau, C., 2014. Trading Away Democracy. How CETA's investor protection rules threaten the public good in Canada and the EU. Amsterdam/ Berlin/Brussels/Montreal/Paris/Ottawa/Vienna: Aitec, AK Vienna, CCPA, CEO, Council of Canadians, CUPE, EPSU, German NGO Forum on Environment \& Development, FoEE, PowerShift, QCEA, RQIC, Trade Justice Network, TNI, T\&E. Available from: http:// canadians.org/sites/default/files/publications/trading away 1114.pdf [Accessed 10 Feb 2015].

EBU, 2014. EU negotiations on TTIP and the exclusion of audiovisual services: EBU policy note [online]. Available from: http://www3.ebu.ch/files/live/sites/ebu/files/Publications/ Position\%20Papers/EBU Position EN Trade\%20negotiations\%20on\%20TTIP 14.07. 2014.pdf [Accessed 15 Apr 2015].

European Union \& Council, 2010. Directive 2010/13/EU of the European Parliament and of the Council of 10 March 2010 on the coordination of certain provisions laid down by law, regulation or administrative action in Member States concerning the provision of audiovisual media services (Audiovisual Media Services Directive). Official Journal of the European Union, 15.4.2010.

FCCD (Coalition française pour la diversité culturelle), 2012. Accord économique UE Canada: la France en faveur de l'exclusion horizontale desservies audiovisuels [EU Canada trade agreement: France in favour of the horizontal exclusion of audiovisual services], Press release, 17 December [online]. Available from: http://www.coalitionfrancaise.org/accord economique ue canada la france en faveur de lexclusion horizontale des services audiovi suels/ [Accessed 12 May 2015].

Frau Meigs, D., 2012. La diversidad cultural y la sociedad de la información: nuevas config uraciones y tendencias emergentes en cuestiones trasnacionales [Cultural Diversity and Information Society: new configurations and emergent tendencies in transnational issues]. Quaderns del CAC, 38 (XV), 4555.

Fuchs, P., 2014. Investor state dispute settlement. In: S. Sinclair, S. Trew, and H. Mertins Kirkwodd. Making sense of the CETA. An analysis of the final text of the Canada Euro pean Union Comprehensive Economic and Trade Agreement. Ottawa: Canadian Centre for Policy Alternatives, 1318.

Geraghty, E. and Cingotti, N., 2014. The hidden cost of EU trade deals: investor state dis pute settlement cases taken against EU member states, 4 December, Friends of the Earth Europe [online]. Available from: http://www.foeeurope.org/sites/default/files/publications/ hidden cost of eu trade deals 1.pdf [Accessed 10 Mar 2015].

Graber, C., 2006. The new UNESCO Convention on cultural diversity: a counterbalance to the WTO? Journal of international economic law, 9 (3), 553574.

Grece, C., A., Schneeberger, A., and Valais, S., 2015. The development of the European market for on demand audiovisual services. Report prepared by the European Audiovi sual Observatory (EAO) for DG Connect. Available from: https://ec.europa.eu/digital agenda/en/news/development european market demand audiovisual services [Accessed 12 Jun 2015].

Guerrieri, P., Iapadre, P.L. and Koopmann, G., eds., 2005. Cultural Diversity and Interna tional Economic Integration. The Global Governance of the Audio visual Sector. Chel tenham: Edward Elgar.

Guèvremont, V., 2013. Preliminary reflection on the implementation of the Convention on the Protection and Promotion of the Diversity of Cultural Expressions in the digital age. Report, submitted to the 4th Conference of the Parties to the Convention on the Protec tion and Promotion of the Diversity of Cultural Expressions (UNESCO, Paris). Available from: http://papers.ssrn.com/sol3/papers.cfm?abstract id=2490278 [Accessed 12 Jun 2015].

Hübner, K., 2011. Canada and the EU. Shaping transatlantic relations in the twenty first cen tury. In: K. Hübner, ed. Europe, Canada and the Comprehensive Economic and Trade Agreement. Abingdon: Routledge, 18.

Hübner, K., 2014. TTIP and CETA. Remaking of the Atlantic economy? In: J. Roy and

R. Domínguez, eds. The Transatlantic Trade and Investment Partnership between the European Union and the United State. Miami, FL: Florida European Union Center/Jean Monnet Chair, 113. 
Kulesz, O., 2014. UNESCO Convention on the Protection and Promotion of the Diversity of Cultural Expressions: Analysis of Parties' periodic reports and contemporary digital trends. Information Document prepared for the 8th ordinary session of the Intergovern mental Committee for Protection and Promotion of the Diversity of Cultural Expressions (UNESCO, Paris). Available from: http://en.unesco.org/creativity/sites/creativity/files $/ 8 \%$ 20IGC INF\%205 Digital EN.pdf [Accessed 12 Jun 2015].

Leblond, P., 2010. The Canada EU Comprehensive Economic Trade Agreement: more to it than meets the eye. Policy options, 21 (7), 74 78. Available from: http://policyoptions. irpp.org/issues/immigration jobs and canadas future/the canada eu comprehensive eco nomic trade agreement more to it than meets the eye/ [Accessed 12 May 2015].

Loisen, J., 2015. The implementation of the UNESCO Convention on the Protection and Promotion of the Diversity of Cultural Expressions in EU external relations. In: E. Psy chogiopoulou, ed. Cultural Governance and the European Union Protecting and Pro moting Cultural Diversity in Europe. Basingstoke: Palgrave Macmillan, 210224.

Maltais, A.L., 2014a. L'Accord économique commercial et général/Canada Union europé enne. Faut il célébrer "l'évocation culturelle"? [The Comprehensive Economic and Trade Agreement. Should we celebrate the "cultural evocation"?] Lettre sur le commerce inter national, $\mathrm{N}^{\mathrm{o}}$ 5, November. Available from: http://www.irec.net/upload/File/lettrecom merceno5novembre2014vd.pdf [Accessed 4 Feb 2015].

Maltais, A.L., 2014b. Cultural exceptions. In: S. Sinclair, S. Trew, and H. Mertins Kirk wodd. Making sense of the CETA. An analysis of the final text of the Canada European Union Comprehensive Economic and Trade Agreement. Ottawa: Canadian Centre for Policy Alternatives, 4955.

Mattelart, A., 2006. Diversidad cultural y mundialización [Cultural diversity and mundial ization]. Barcelona: Paidós.

Mosco, V., 1996. The political economy of communication. Rethinking and renewal.

London: SAGE.

Obuljen, N. and Smiers, J., eds., 2006. UNESCO's Convention on the Protection and

Promotion of the Diversity of Cultural Expressions. Making it work. Zagreb: Institute for International Relations.

Ofcom, 2014. International Communications Market Report. Research document by Ofcom [online]. Available from: http://stakeholders.ofcom.org.uk/binaries/research/cmr/ cmr14/icmr/ICMR 2014.pdf [Accessed 12 Jun 2015].

Puppis, M., 2008. National media regulation in the era of free trade. The role of global media governance. European journal of communication, 23 (4), 405424.

Richieri Hanania, L., 2012. Cultural Diversity and Regional Trade Agreements The Euro pean Union Experience with Cultural Cooperation Frameworks. Asian journal of WTO \& international health law and policy (AJWH), 7 (2), 423456.

Richieri Hanania, L., ed., 2014. Cultural Diversity in International Law. The effectiveness

of the UNESCO Convention on the Protection and Promotion of the Diversity of Cultural Expressions. Abingdon: Routledge.

Richieri Hanania, L. and Ruiz Fabri, H., 2014. Introduction: the effectiveness of the UNESCO Convention on the Protection and Promotion of the Diversity of Cultural Expressions. In: L. Richieri Hanania, ed. Cultural Diversity in International Law. The effectiveness of the UNESCO Convention on the Protection and Promotion of the Diver sity of Cultural Expressions. Abingdon: Routledge, 122.

Rioux, M., Deblock, C., Gagné, G., Tchéhouali, D., Fontaine-Skronski, K., and Vlassis, A., 2015. For a diversified Networked Culture. Bringing the Convention on the Protection and Promotion of the Diversity of Cultural Expressions (CPPDCE) in the digital age. Quebec: Centre d'études sur l'intégration et la mondialisation (CEIM). Available from: 2015]. http://www.ieim.uqam.ca/IMG/pdf/rapportcdec-court-en-vfinale.pdf [Accessed 10 Jun

Sauvé, P. and Steinfatt, K., 2000. Towards multilateral rules on trade and culture: protective regulation of efficient protection? In: Productivity Commission and Australian National

University, ed. Achieving better regulation of services. Canberra: AusInfo, 323346.

Sinclair, S., Trew, S., and Mertins Kirkwodd, H., eds., 2014. Making sense of the CETA. An analysis of the final text of the Canada European Union Comprehensive Economic and Trade Agreement. Ottawa: Canadian Centre for Policy Alternatives. 
Souyri Desrosier, C., 2014. EU protocols on cultural cooperation. An attempt to promote and implement the CDCE within the framework of bilateral trade negotiations. In: L . Richieri Hanania, ed. Cultural Diversity in International Law. The effectiveness of the UNESCO Convention on the Protection and Promotion of the Diversity of Cultural Expressions. Abingdon: Routledge, 209224.

The Council of Canadians, 2013. CETA and Corporate Lobbying. Corporations hold power over negotiations. Factsheet, March 14 [online]. Available from: http://www.canadians. org/content/factsheet ceta and corporate lobbying corporations hold power over negotia tions [Accessed 10 Mar 2015].

Thiec, Y., 2014. From a moratorium in the conflict between trade and culture to the creation of a digital deal for cultural diversity. In: L. Richieri Hanania, ed. Cultural Diversity in International Law. The effectiveness of the UNESCO Convention on the Protection and Promotion of the Diversity of Cultural Expressions. Abingdon: Routledge, 95106.

Trew, S., 2014. Public procurement. In: S. Sinclair, S. Trew, and H. Mertins Kirkwodd. Making sense of the CETA. An analysis of the final text of the Canada European Union Comprehensive Economic and Trade Agreement. Ottawa: Canadian Centre for Policy Alternatives, 2429.

UNESCO, 2005. Convention on the Protection and Promotion of the Diversity of Cultural Expressions. Paris: UNESCO.

Vlassis, A., 2011. La mise en ouvre de la Convention sur la diversité des expressions cul turelles. Portée et enjeux de l'interface entre le commerce et la culture [The implementa tion of the Convention on the Diversity of Cultural Expressions. Scope and implications of the interface between trade and culture]. Etudes internationales, 42 (4), 493510.

Vlassis, A., 2014. AECG et industries culturelles: entre avancement positif et risques poten tiels [CETA and cultural industries: between positive advances and potential risks]. $\mathrm{Cul}$ ture, commerce et numérique, 9 (8), 4 5. Available from: http://www.ieim.uqam.ca/ IMG/pdf/oif volume9 numero8octobre 2014ceim.pdf [Accessed 10 Mar 2015].

Vlassis, A., 2015. Négociations commerciales récentes et industries culturelles: de la con frontation politique à la réconciliation normative? [Recent trade negotiations and cultural industries: from political confrontation to normative reconciliation?] In: C. Deblock, J. Lebullenger, and S. Paquin, dir. CETA entre UE et Canada, du dialogue au libre échange transatlantique. Montreal: Presses universitaires de Montréal [forthcoming].

Vlassis, A. and Richieri Hanania, L., 2014. Effects of the CDCE on trade negotiations. In: L. Richieri Hanania, ed. Cultural Diversity in International Law. The effectiveness of the UNESCO Convention on the Protection and Promotion of the Diversity of Cultural Expressions. Abingdon: Routledge, 2539.

Von Schorlemer, S. and Stoll, P., eds., 2012. The UNESCO Convention on the Protection and Promotion of the Diversity of Cultural Expressions. Explanatory notes. Berlin: Springer.

Wunsch Vincent, S. and Hold, A., 2011. Towards coherent rules for digital trade:building on efforts in multilateral versus preferential trade negotiations. Working paper N0 2011/ 64, July. Bern: Swiss National Centre of Competence in Research.

Zimmermann, O. and Geißler, T., eds., 2015. TTIP, CETA \& Co., Die Auswirkungen der Freihandelsabkommen auf Kultur und Medien [TIP, CETA \& Co. The impact of free trade agreements on culture and media]. Berlin: Deutscher Kulturrat. 